\title{
Challenges of Female Journalists in Bangladesh
}

\author{
Md Nurus Safa ${ }^{1, *}$, Tahera Akter ${ }^{2}$ \\ ${ }^{1}$ The School of Journalism and Communication, Central China Normal University, Wuhan, China \\ ${ }^{2}$ School of Management, Wuhan University of Technology, Wuhan, China
}

Email address:

nsafadu@yahoo.com (M. N. Safa)

\section{To cite this article:}

Md Nurus Safa, Tahera Akter. Challenges of Female Journalists in Bangladesh. Humanities and Social Sciences.

Vol. 3, No. 5, 2015, pp. 207-214. doi: 10.11648/j.hss.20150305.17

\begin{abstract}
Journalism is a challenging profession in Bangladesh where female were less encouraged to be a journalist. In recent time Bangladesh is encouraging her women to work outside of home. A significant number of women are involved in journalism. They are contributing to the society for economic prosperity and changing the attitude towards the development concept and process. A salient change has come into the social attitude which is symbolized by women's advancement in journalism sector. These contributions also are paving the way for female and human emancipation. So it is important to find out what are the challenges that women journalist's face in their professional environment. The study has taken a survey of 100 female journalists from television, newspaper and online media of Bangladesh. The study has taken 6 in-depth interviews from media critics. The female journalists recognized stereotyped attitudes, unreasonable treatment, harassment by male colleagues and job insecurity as the common reasons that make them to give up the profession.
\end{abstract}

Keywords: Female Journalists, Challenges, Journalism, Bangladesh

\section{Introduction}

Kazi Nazrul Islam, national poet of Bangladesh wrote - the Good done by the civilization, half created by man and rests by the women. This is an eternal statement about the development of human civilization. From the dawn of the civilization women and men have worked together to make the future brighter. In Bangladesh female journalists have held a prominent place in media. Nevertheless, the number of female journalists is on the rise in Bangladesh, along with the growing number of print and electronic media. They are very eager to work in all the sector of journalism because they are brave, courageous and adventurous, but there is little recognition of their issues and their struggles.

\section{Research Background}

In the history of newspaper of Bangladesh we can easily find out that the society wasn't more encouraging to do work outside for female. Pre independent era women are not acceptable to work outside. Nevertheless a few female contributed to change the society by their writings. Monthly Begume is a milestone of its. In fact this periodical was the forum of female writers of that period. At this stage regular newspapers introduced women pages. As a result from that time and yet today the women pages are mainly edited and wrote by female.

The female journalists recognized stereotyped attitudes, unreasonable treatment, harassment by male colleagues and job insecurity as the other reasons that prompt them to give up the profession. According to workshop on "Women in Bangladesh Media 2008" only six per cent female keep going in the main stream of journalism. The reality pointed out that females were paid less as compared to male colleagues in some media houses, and they worked under huge social pressure and mobility problems. Participants urged removal of gender imbalance in media, and there is need to provide female with equal opportunities as enjoyed by men. Recognition of their work and better wages are needed to encourage female journalists to stay in the profession. Female journalists should be encouraged to work on hard beats, which are reserved for male journalists.

\section{Research Significance}

When I have learned to feel the social context, I remarked that salient gender discrimination is big problem in our society. This problem is deepening day by day in our society, which is a vast obstacle for developing nations. As studying and working in media line I have seen here also having huge 
gender discrimination. Female Journalists fail to show up their own creation by facing internal and external gender discrimination. I believe that any country never be developed if the gender discrimination is exist with her half part of nations like Bangladeshi female. In this view I am very much interested to study the challenges of female journalists in Bangladesh. I think if we much study the problem and solution of female journalists definitely in society will bring out a good output. Today or tomorrow or after generations this output will exist in the society and gender discrimination will be removed from the society for ever. Then nations will move ahead in touch of modernization and development. In Bangladesh we know women constitute half of the nation. But they don't have sufficient participation in journalism. The next or upcoming improvement of society depends on cooperative and fruitful implementation of gender discrimination policies for Bangladesh.

\section{Research Objectives}

The objective of the paper had driven from the problem statement and the significance of the studies. The main objective of the study was explored the national culture and work behavior of journalism for female journalist regarding Bangladesh.

\section{Main Research Questions}

Main research questions under this study have been determined as follows:

1. What are the challenges that female journalists face in their professional work?

2. Is there any gender discrimination in the media houses of Bangladesh?

3. What are the roles of female journalists, particularly within the context of violence?

4. What are the internal and external problems of the real situation of female journalists?

\section{Literature Review}

In Bangladesh, presently there are mainly four categories of journalists are working- first the employees of foreign press, second the employees of urban press, third the employees of rural or semi-urban press and the fourth grassroots representatives of urban press. In all categories a significant number of female are working and contributing a lot in the changing process of social out look towards female. It's external outlook of female journalists of Bangladesh. If we try to lookup of its internal condition we can easily estimate that female have always been discouraged to do journalism in Bangladesh. In Bangladesh female's participation in journalism, including electronic and print media marked a rise in last couple of years but most of them give up their profession for various problems.

In recent decades, they have not made much progress in journalism because of disparities. The female are facing discrimination in education, employment, and access to resources and services, in particular healthcare. Discrimination against female works more faintly through the effects of sex-related beliefs and prejudices. Basically, In Bangladesh Socio-cultural factors play an important role in advancing or hindering women's access to journalism. (2003). It's true that society will gain a large benefit if we make gender balance in the media. In a perfect world male and female would be equally contribute in the media both as reporters, editors and as subjects in articles.

Though Bangladeshi constitution guaranteed equal rights in access for their female but female generally remain far from enjoying equal rights. According to the report of "international federation of journalists 2014", apart from the killing of bloggers and numerous attacks on journalists, female journalists have also been specially targeted in the violence against the media by fundamentalist forces like the Hefajat e Islam. Female have been attacked and ridiculed while covering public meetings and stopped from reporting in the field. Journalist Nadia Sharmeen was on assignment to cover a Hefajat meeting, when she was brutally attacked and subsequently hospitalized. Her employer Ekushey TV supported her initially including paying hospital bills, but support petered out after a while. The Bangladesh High Court later directed the government to provide her with medical treatment free of cost. (Galhotra, 2013)

Prof GitiaraNasreen (2003) conducted a research on "Women in Bangladesh media" and concluded as follows:

"The main reason of this problem is the legal position of female is still ruled by religious laws when it comes to legacy, marriage, divorce, and child custody. Religious laws are privileged over constitutional guarantees, working against the interest of female journalist. Attitudes in society still stand against gender equality. Very often female are not aware of their rights, even when they are, female who depend on male protection are convinced that it's not in their best interests to claim those rights."

In recent times the trend is changing, a significant number of Bangladeshi female are becoming involved in journalism, especially in reporting along with the growing number of print and electronic media. It's proving that female can get in any kind of challenging job like journalism alongside male, and female are doing well. There are more than $40 \mathrm{TV}$ channels and $11 \mathrm{FM}$ radio stations in Bangladesh, along with two dozens of newspapers and online newspaper. In Bangladesh many female have been doing noteworthy work as journalists over the last decade. But the number of their presence in both print and electronic media is unthinkably less than expected. More and more women have been joining the ranks of journalists in the last few decades, but they still tend to occupy the lowliest jobs. Executive and editorial positions are continuing reserved for men. But it is time to recognize the challenges and explore the opportunities for women to encourage them.

American journalist Mary Temple Bayard (1893) said "The newspaper is the educator of the public, and men and women who write in newspapers have the best opportunities for 
creating public opinion. They know their colleagues of the other sex watch them with an attention naturally critical, but not always sympathetic; neither is there a royal road especially prepared or made smooth for either sex. A fair field and no favor must suffice for women in journalism. There is no claim to be set forward on the basis of sex. Women who have succeeded in journalism have succeeded as journalists and not as women, and this along the same lines on which men have succeeded."

In south Asia female journalists are facing discrimination of work assigned, promotional opportunities, sexual harassment, lack of maternity benefits and poor support conditions for working mothers. Yet there are a number of female journalists who still strive to get the story and strive for fair and gender sensitive reportage. They put their lives at risk and try to uncover different and more human dimensions of the conflict they cover, seeking to speak to women survivors to find another story. They learn to survive with courage amidst great odds.(CNC, 2013)

Cheryl Lindsey Seelhoff said: That is true of most professional female in journalism, specifically in the current affairs slots women aspired to, family life set serious limitations. Child rearing and family and domestic responsibilities without adequate support services were cited as important barriers to advancement. For instance, it restricted travelling on assignments for female with small children or made female think twice before accepting jobs that required long, late and irregular hours. This included some kinds of supervisory jobs in journalism. It was suggested that female journalists should be able to work flexible hours but this is not practical in news organizations. Another point made was that domestic work (and social norms) prevented female, unlike men, working at their careers outside the office either by improving their knowledge or engaging in office politics and 'drinking with the boss'. The possibility of getting men to share domestic work was considered more utopian than getting domestic help or domestic appliances. (Shellhoff, 2007)

The Bangladesh NariSangbadhik Kendra (BNSK) is the oldest women journalists' organization in Bangladesh and was established in 2001. According to BNSK 2006, the number of female journalists is increasing in Bangladesh, but their numbers are still woefully low. BNSK estimates around 6000 male journalists and only around 300 female journalists in Bangladesh. Sadly, there are fewer female at the policy making level. In newsrooms, female journalists often face disparities in news beats like energy, economic, political, parliament, crime, sports and election commission, their numbers are negligible. With poor facilities and a discouraging environment, upward mobility is a struggle. Female suffer discrimination in training, recruitment and promotion and denied decision making positions. According to the report of South Asia Media Freedom and Solidarity Project (SAMSN) In Bangladesh TV female journalists are often treated as sex objects and expected to act and dress in that manner. They are rarely seen as serious journalists. Miserably sexual harassment in the workplace is increasing.
This is largely hidden and undocumented and female journalists who raise sexual harassment charges against colleagues or seniors are often at risk of losing their jobs and their charges are either not taken up seriously or dismissed as false.

Violate rights of female journalist is not new invention but it's verify on society to society. The EAJA reports that in Eastern Africa, some media houses "violate rights of female journalists such as presenting them as sexual objects; sexual harassment, intimidation, abuse, undervaluing or ignoring their work, successes, efforts, rights and by symbolically destroying or frustrating them". Sexual harassment remains an unspoken problem. Unnecessary touching, sending of unwanted emails, text messages, display of pornographic pictures in the workplaces, sexual comments etc, are generally considered as forms of sexual harassment, the impact of which can have a debilitating effect on the personality, working life and social behavior of the person harassed. (Wide-Gayles, 1981)

In previous time there are so many researchers and Scholars tried to find out female journalists condition in Bangladesh. Definitely they did very good works. Sometimes they skim some reasons according their research purpose and their time limitation. They showed up their research view. It is very clear in this position I am paying attention to do research as a brought section. I will enter the deep position of female journalist in Bangladesh. I believe that after this research I will be able to come out the real scenery of Bangladeshi female journalists.

\section{Methodology}

In this study the author has used survey method and indepth interview. A descriptive survey attempts has been conducted to analyze picture or documents of current conditions or attitudes that is, to describe what exists at the moments.

Non probability sample is selected to find out survey respondents. The study has taken a survey of 100 female journalists from television, newspaper and online media of Bangladesh according to their attachment of work, working pattern and working facilities. The study has taken 6 in-depth interviews from media critics whose views are enriched this research. These interviewees are selected purposively. Both primary and secondary data are important for any study. In the proposed study primary data were collected through interviews, observation and survey. In this study both the written and oral documentary data were been consulted for better research. In addition to this, secondary data from multiple sources e.g. books, journals, newspapers, professional, local chambers and commerce bulletin, website etc has also been consulted.

\section{Data Presentation from Survey}

In this section data collected from survey method and indepth interview method have been presented. One hundred 
journalists are engaged in different media houses such as print media, online media and electronic media journalism.

\section{Challenges Faced by Women Journalists}

Women journalists face many kinds of professional challenges in the media houses. After initial resistance, even women journalists start justifying organizational insensitivity. They are instrumental in perpetuating lack of recognition of women's special needs and functions in society Childbirth, childcare, confinement, security after night duty etc. Many believe the myth that women journalists have limitations within organizations since they cannot do night shifts.

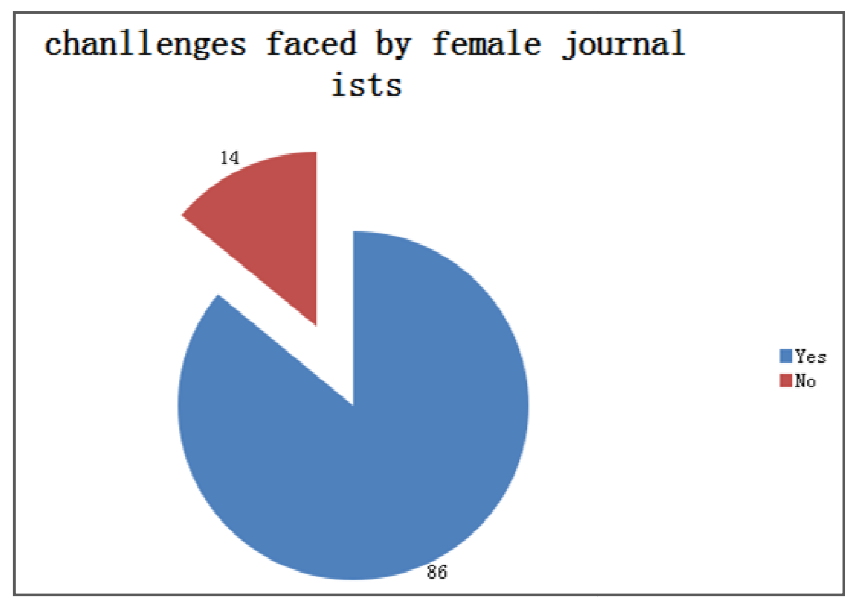

Figure 1. Challenges faced by female journalists.

The study shows that $86 \%$ respondents face challenges in the media houses while $14 \%$ respondents mentioned that they did not face any challenges.

Many women journalists said that there is a dilemma in childcare vs. profession. Effect of work on marital relations differs between male journalists and women journalists. Longer maternity leave is important since confinement and childcare are very demanding on health and emotions. This would usually be required once or twice in all working life so no big deal.

For more than a decade, Sheuli Akter worked as a journalist for Bangladesh's leading news agency UNB and now defunct English newspaper The Bangladesh Observer in various capacities. She first engaged herself with news media during her university life in the 2000s.

Sheuli Akter said "I was really upset after leaving my job. I love journalism. It's my heart. It's the blood in my veins. I can't ever keep myself away from writing news stories".

She returned to her news agency work after taking maternity leave when her baby was only four months old, in October 2012. But two months after her return, she had to leave because of surrounding circumstances which still impede the professional careers of many Sheuli Akter-like new mothers in Bangladesh.

Sheuli Akter said a portion of Bangladesh employers still don't want to try to understand that a woman gains more maturity and can undertake and perform her responsibilities even better when she becomes a mother. Even some fellow colleagues sometime are not supportive enough to the mother of a new born.

Women journalists are conscientious, diligent and people relate more easily to us. However, male bosses do not give credit for professionalism instead they speak of women exploiting their gender. It is the challenge which maximum women journalist face.

\section{Beat Covered by Female Journalists}

Women journalists have covered softly beat as education, literature, culture, female page, children and woman affairs, and latest in food or fashion. This is not lacking of quality of female journalists. If she wants to go covered political news, crime report, violence report and like that other hard beat society will hinder them. They will be harassed in mentally, physically and socially. Though they have proper knowledge about on that's challenging beats.

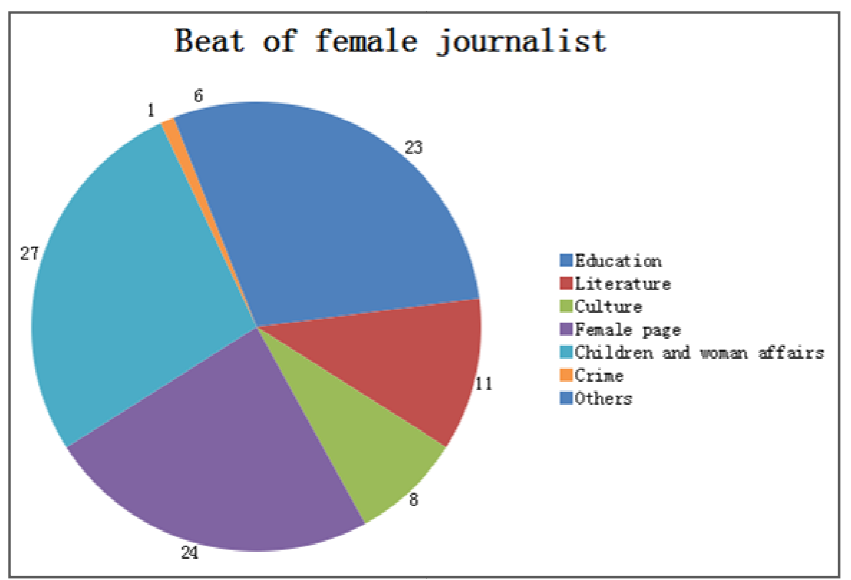

Figure 2. Beat covered by female journalists.

The above figure shows that women journalists have covered children and female affairs beat and page are the highest consideration ( $27 \%$ and $24 \%$ ). In the media houses, there is a general consideration that crime beat is only for male journalist. The study also finds that there is only one female journalist found who worked in the crime beat.

One example, in visual media from the beginning of BTV (Bangladesh Television) we have not seen any female reporter to cover a vital reporting like diplomacy, economics, court, parliament's news etc. As a media representative they don't get any opportunity in foreign tour. Beside this in the subject of professions they face discrimination. But TV channel are getting exceptional role in female not only news presenting but also news reporting like ETV, NTV, ATN BANGLA. There are some channels which are doing fantastic job in news sector. Here females are showing their skill effectively. Even they are focusing their expertness in overseas reporting or very sensitive reporting like crime. The contribution of the TV channel has changed our social norms 
and values about our female side. Women's representation in the media (both electronic and print) is indeed pitifully peripheral in Bangladesh.

\section{Covering Violence or Conflict Related Events}

There is a general consideration that, violence and conflict related events will covered by male journalist. This is our social and mental problem.

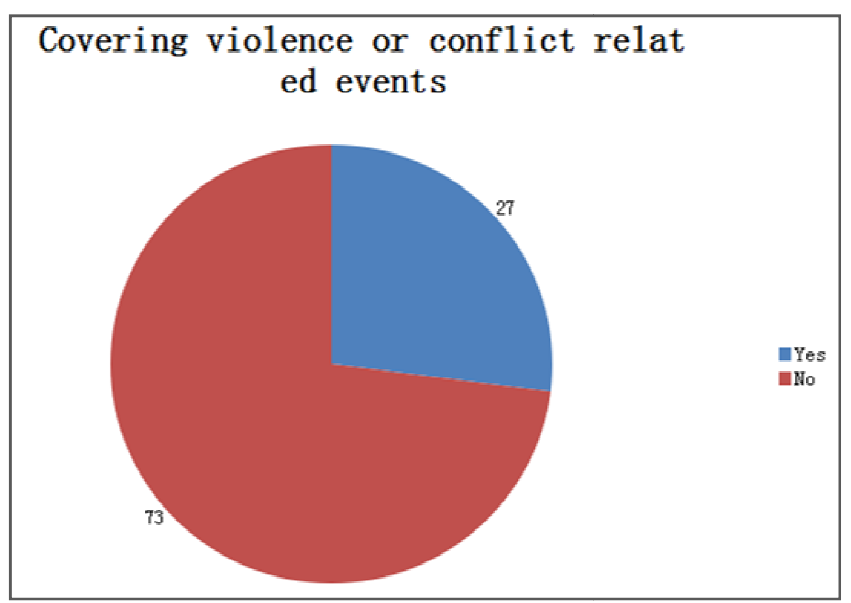

Figure 3. Covering violence or conflict related events.

The study found that $27 \%$ female journalists have experience of covering violence and conflict related event, While $73 \%$ female journalists have no experience of covering violence and conflict related news and events.

Samia Zaman, News Reader of the ETV (Ekushe Television) mentioned, "Even in the $70 \mathrm{~s}$ the women in western media had to fight continuously for their place. And even though as we are fighting for our place, women are seen as the glamorous touch, but we still have to prove ourselves through our skills. Though women are working, there are so few in the policy and decision-making levels of the organization. We have to work to change this situation. She believes if all the factors acted well then equal distribution of covering by female may enhance.

\section{Gender Discrimination in Media Houses of Bangladesh}

Women journalists have to work twice as hard as male colleagues and have to constantly battle suggestions or perceptions that we are using sexuality to get ahead in our careers. We are more vulnerable than male colleagues to gossip, to promotion prospects, and too age is a factor for discrimination. Bangladesh has been campaigning to end gender-based discrimination in the media and censorship against women journalists. Women journalists in Bangladesh face many challenges, including low pay, and they lack protection from threats, harassment and vexatious litigation.

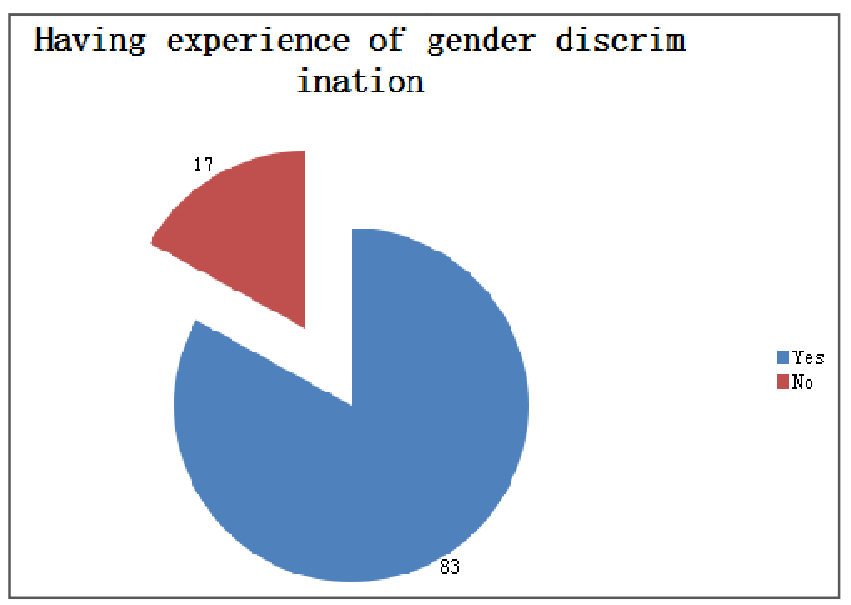

Figure 4. Gender discrimination in media houses.

The above figure shows that $83 \%$ female journalists face gender discrimination in their houses while $17 \%$ respondents mentioned that they have no experience about this.

Though some media have official gender policy in recruitment of staffs, the daily gives priority to competent female candidates. The Editor, on different occasions, instructed the senior staffs to encourage female staffs and said he wants the male-female staff ratio to be even.

The newspaper has an unwritten policy for zero tolerance about gender discrimination and has made encouraging instance in this regard but reality is absence. "After observing the status of women employment in the media industry in Bangladesh and learning about women's treatment at different newspaper and electronic media houses, I conceived a very pessimistic idea and was quite disappointed," a woman reporter said, as she was sharing her experience. But when she first met the Editor and sought a job in the daily, his words changed her impression and she found it most encouraging, according to her.

\section{Facing Internal Problems}

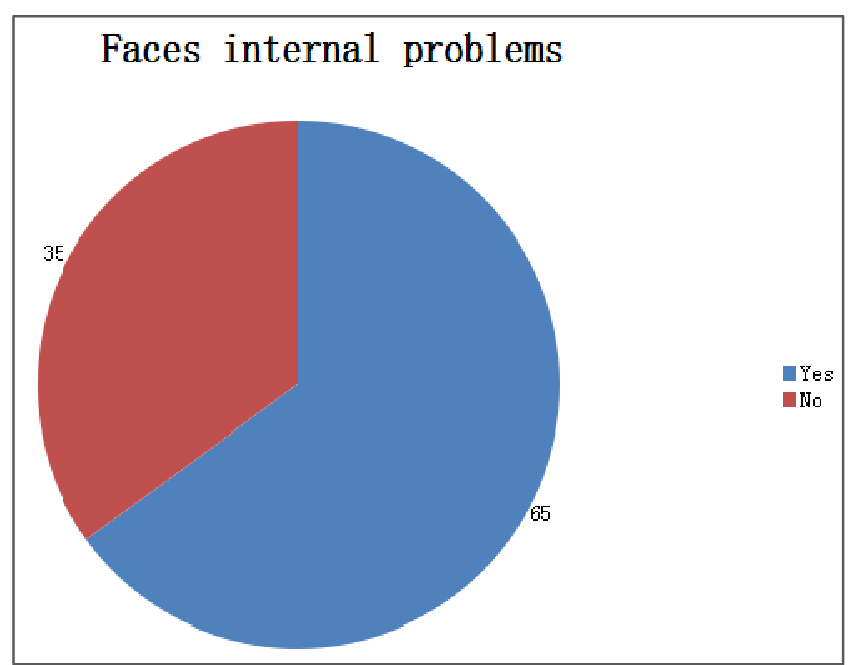

Figure 5. Internal problems face by women journalists.

Women journalists have faced different kinds of internal 
and in media house problems associated with gender discrimination. Firstly, in internal they face family problem. In society father and mother are not allowed their daughter to work in Media house. They always think it is an odd job. Secondly, after marriage husband don't encouraging her to continue journalism profession as carrier because after marriage she couldn't provide enough times to the family and if baby comes she will not able to fostering the infant as well. Sometimes he gives the some restriction to choose profession like journalism.

The study has shown that $65 \%$ female journalists have faced internal and in house problems while $35 \%$ respondents have no experience with this problem.

\section{Facing External Problems}

Women journalists have faced different kinds of external and outdoor problems are associated with gender discrimination. Sexual harassment in media house by colleague or boss is one of the external problems. Now it is considered as a part of work culture in media organizations in Bangladesh but women either do not know how or for a wide variety of reasons choose not to do anything about it. They are exposed to several forms of physical and mental violation at home and media house when they choose to work outside.

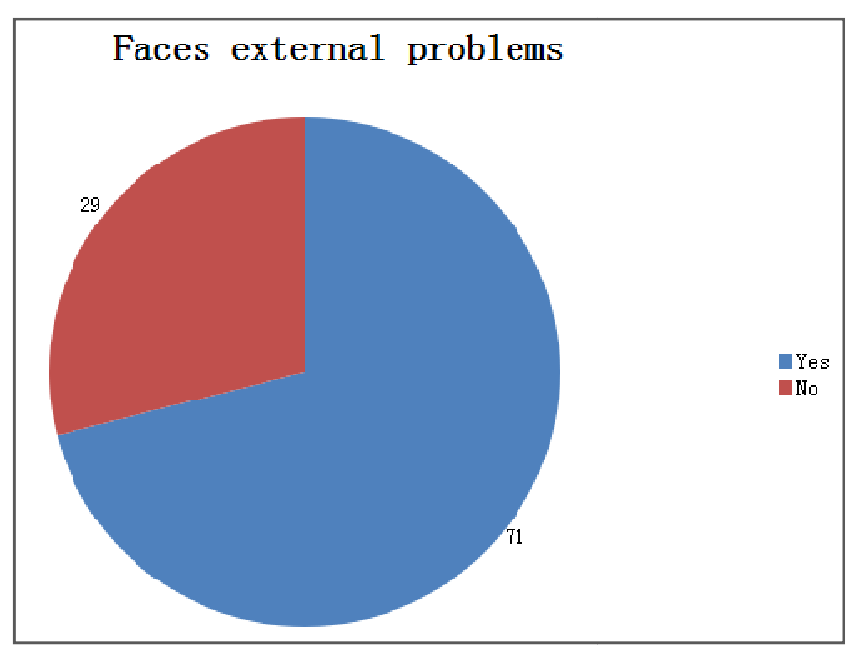

Figure 6. External problems face by women journalists.

The study has shown that 71 percent female journalists have faced external and outdoor problems while 35 percent respondents have no experience with such kind of problems. The respondents mentioned such kinds of problems are eve teasing, sexual harassment, mental and physical torched etc.

\section{Data Presentation from In-Depth Interview}

For qualitative research in-depth interviews of noted six academician and women journalists has been conducted. The impact and results from in-depth interview are presented in below:
Nadia Sharmin a senior correspondence of ETV News mentioned that, the situation for women journalists in Bangladesh is getting riskier day by day. With the expansion of electronic media, the number of women working as journalists has certainly increased. But they face a host of problems including not being paid at the same levels as their male counterparts and being subject to sexual discrimination. We rarely see women as decision makers and media ownership is not yet in their hands, and freedom with which they can report can vary from urban to rural places. And at present, with the rise of groups like Hefajat-e-Islam (a religion based extremist group) and their demands for banning the free association of men and women in public spaces, media houses steer clear of sending women journalists to cover their events, thereby restricting the movement of women journalists. These extremists attack women journalists verbally, even physically as seen in my case.

Farida Yasmin, the editor in charge of the women's page at Ittefaq, believes that the traditional family needs to adjust its attitude to the changing Bangladeshi society. "Parents don't raise any questions when their daughter wants to be a doctor who works late at night at a hospital, so why such concern when their daughters want to work for a newspaper or a television channel," Yasmin asked. She added, "That attitude will only change if enough women are willing to take up the challenge and overcome the obstacles facing them in journalism."

Bangladesh's culture is conservative, especially in its attitude towards the role of women in the home and society. Marriages are often arranged, wives are expected to stay home and take care of the family, and when women want to work, parents invariably play a big role determining their career choices. "Traditionally, the attitude in our society has been that women need to fulfill their commitment to their family first, so Bangladeshi women have felt compelled to stay home," said Afroza Bulbul, "It's only been in the past decade that Bangladeshi women have begun to think about a career."

Working at a sub-editor's desk on a Bangladesh newspaper is considered not as important a job as gathering the news, so a sub-editor doesn't make as much money as a reporter. Given the issues, some Bangladeshi media companies feel that women journalists can be more trouble than they are worth. ShahidUllah added that it's not uncommon for a newspaper to request that his department send a male student to a job interview. There have been reports that the management of many media companies is reluctant to include women in their reporting team, and when they do, they assign to cover women's and children's issues.

Despite the barriers and challenges, Bangladeshi women are showing strong interest in journalism as a career. Many young women come to Farida Yasmin and ask her what career prospects in journalism are like. Her answer: "I encourage them to be journalists, if they are willing to work hard to achieve their dreams. But I also say that they will have to work harder than their male colleagues to do that." 


\section{Discussion and Findings}

Women journalists have very little access to equal employment. In fact a large number of organizations often deny female promotions on the flimsy excuse that they cannot do night duty. Women journalists have to work twice as hard as male colleagues and have to constantly battle suggestions or perceptions that they are using sexuality to get ahead in their careers. They are more vulnerable than male colleagues to gossip, to promotion prospects; and age too is a factor for discrimination.

Women journalists are still adopting a victim stance refusing to acknowledge the many gains they have made because that might mean having to admit there is an even playing field for all journalists. The fact is that there are also those who have developed a tangible strategy for negotiating their careers.

Women are employed in the media now since they are available at lower salaries or on the contract system. In such circumstances gender fair reporting and practices are more difficult to promote. And sometimes female journalists are in fear to promote real news of different sections due to authoritarian behavior of the concern institutions.

Women journalists start justifying organizational insensitivity. They are instrumental in perpetuating lack of recognition of women's special needs and functions in society childbirth, childcare, confinement, security after night duty etc. Many believe the myth that women journalists have limitations within organizations since they cannot do night shifts. Though, the concern organizations are not up to the mark the facilities for the night shift to female journalists.

Women journalists are conscientious, diligent and people relate more easily to us. However, male bosses do not give credit for professionalism instead they speak of women exploiting their gender. Sometimes when the female journalists got recognition from other organization then her concern organizations promote her talents, though that's kind of instance are very few.

Job segregation was an issue of significance for many of the respondents. 24.7 percent feel that they do not have access to all areas of work and that lifestyle, arts, gender, fashion and education are traditional areas reserved for women. But 87.3 percent believe that women have capability in all areas of journalism.

Some of media companies are sensitive to the security issue and provide transport for their staff members. But many other media house doesn't provide such kind of facilities, though some organizations have the ability to provide such facilities to her staffs. Despite the barriers and challenges, Bangladeshi women are showing strong interest in journalism as a career.

\section{Recommendations}

For good participation of female journalists in all sectors of media author has given some suggestion. I think if we do that, female journalist will be more interest to do on these professions. Female journalists must break the culture of silence to enjoy their freedom of expression, freedom of mobility, freedom of observance of womanhood, freedom of choice to enjoy their lives, and freedom of protest against all the odds and obstacles they face every moment, everyday, everywhere. Women and men can accept to change their mindset positively to make a radical change. Training workshops is to be arranged for personal working in women's magazines, newspapers editions and electronic media's related sections. The collaboration between the organizations, public and private working for women's betterment and related media sections should be enhanced.

Government must be more active for solving the female journalist's problems, issues and fields. They should take step according to their laws and legislations.

Social concerns, social activities and social organizations should be take proper step to change the narrow thinking level and mentality from the society. They can work for developing the social conscious and their duty to remove the discrimination from the society with female journalists.

Journalism related organization such as press club is approached and persuade to pay more attention to women's problems. The pages of women' magazines and women edition should be increased, similarly duration of Radio and T.V program needs enhancement

\section{Conclusion}

As a moderate country Bangladesh provides equal status to the women and giving them same facility to the man, though practically it's not working well. But due to the state attachment and positive engagement of the literary women in the field of work the conditions of the women in Bangladesh is changing for better. Undoubtedly, the prevailing situation of women in Bangladesh is changing and approaching towards betterment. Female literacy rate is increasing rapidly and for these reasons attachment of women in the job sector are increasing day by day. More and more women are entering different professions and getting jobs and awareness about women's problems and right is also increasing. The role of media in affecting the change cannot be denied. Women's journalism in Bangladesh shares the credit for this constructive change.

\section{Acknowledgments}

The author is grateful to all the noted academicians, journalists and editors who gave their precious time and allow me interviews and express their valuable opinions regarding my research. It is indeed a great pleasure on my part to express a sense of profound indebtedness to my dearest teacher, Dr. Liu Zhen. I am immensely indebted to him for his guidance, inspiration and encouragement of this research. This work could not have been finalized without his astute supervision. 


\section{References}

[1] Abraham, Amrita. (1988). Asian women journalists take stock. Economic and political weekly, 23(32), 1616-1617.

[2] Ahmed, Shafi et al. (2001). One Decade of Women Leadership in Bangladesh. Alochona Magazine, Retrieved from URL: http://www.magazine.alochona.org.

[3] Bayard, Mary temple. (1893). Women in Journalism. In worlds congress of representative women, Chicago, 435-37.

[4] Bogdan R., Taylor, S., J., (1984). Introduction to Qualitative Research Methods: The Search for Meanings. John Wiley Publishing, 2nd edition: 68.

[5] Brace Ian. (2004). Questionnaire Design: How to Plan, Structure and Write Survey Material for Effective Market Research, Kogan Page Ltd: Londons.

[6] Bangladesh: Unfair treatment discourages women in journalism. (2003). Retrieved march 11, 2014, from http://www.asiamedia.ucla.edu/article.asp? parentid=5711.

[7] Bangladesh: women journalists say "No" to discrimination and demand more protection. Retrieved June 9, 2014, from http://www.article19.org/resources.php/resource/37583/en/ban gladesh:-women-journalists-say-

$\% \mathrm{E} 2 \% 80 \% 9 \mathrm{Cno} \% \mathrm{E} 2 \% 80 \% 9 \mathrm{D}$-to-discrimination-anddemand-more-protection.

[8] Chepesiuk, Ron. (2004). Working as a women journalist in Bangladesh. Retrieved november20, 2014, from http://archive.thedailystar.net/2004/06/14/d406141501214.htm.

[9] CNC report. (2013). Bangladesh Women in Journalism. Retrieved October 27, 2014, from http://en.cncnews.cn/news/v_show/31289_Bangladesh_Wome n_In_Journalism.shtml.

[10] Eckert, Stine. (2009). Bangladesh- A Women in Power and Powerless women? W. Scripps School of Journalism at Ohio University.

[11] Fabrigar, L. R., Wegener D. T., MacCallum R. C., Strahan E. J. (1999). Evaluating the Use of Exploratory Factor Analysis in Psychological Research. Psychological Methods, 4(3), 272 299.

[12] Galhotra, Sumit. (2013). CPJ Asia program Research. Retrieved January 12, 2015, from http://cpj.org/blog/2013/08/bangladesh.php.

[13] Huberman A. M., Miles M. B. (1984). Qualitative Data Analysis: A Source Book of New Methods. New bury Park, CA: Sage Publications.

[14] I, Lakatos. (1970). Falsification and the Methodology of Scientific Research Programmes. Criticism and the Growth of Knowledge, Cambridge UP, 91-196.
[15] International Federation of Journalists. (2009). Getting the Balance Right: Gender Equality in Journalism. Belgium. Retrieved April 20, 2015, from http://portal.unesco.org/ci/en/files/28397/12435929903gender _booklet_en.pdf/gender_booklet_en.pdf

[16] J, Berry. (1980). Introduction to Methodology, The hand Book of Cross-cultural Psychology. Allyn \& Bacon, Inc, Boston, MA. 2: 1-29.

[17] Johnson, D. E. (1998). Applied Multivariate Methods for Data Analysis. Brooks $\backslash$ Cole Publishing Compan, Pacific Grove, CA.

[18] Kline, P. An Easy Guide to Factor Analysis. Routledge: London.

[19] Leedy, P. \& Ormrod, J. (2001). Practical research: Planning and design (7th ed.).

[20] Lutes, Marie, Jean (2008). Front- Page Girls: Women Journalists in American culture and Fiction. The Journal of the Midwest Modern Language Association, 41(1), 124-126.

[21] Leedy, Paul D. and Jeanne Ellis Ormrod (2001). Practical Research: Planning and Design (7th ed.). New Jersey: Merrill Prentice Hall.

[22] Marzolf, Marion. (1979). A history of women journalists. Signs, 4(4), 782-783.

[23] R., K., Yin. (1984). Case Study Research: Design and Methods. Beverly Hill, CA: Sage Publication, 91.

[24] Seelhoff, Cheryl Lindsey. (2007). A Chilling Effect: The Oppression and Silencing of Women Journalists and Bloggers Worldwide. Off our backs a women's news journal, 37(1), 1821.

[25] Seelhoff, Cheryl. (2007). Confronting the Religious right. Off our backs, Women and fundamentalisms issue.

[26] Seshu, Geeta. (2014). The stories women journalists tell women in media in south Asia. South asia media freedom and solidarity project (SAMSN).

[27] The Daily Star. (March 14, 2015). Female journos can play big role in fighting graft: TIB boss. Retrieved May 10, 2015, from http://www.thedailystar.net/city/female-journos-canplay-big-role-fighting-graft-71063.

[28] Wijngaard, Den, Van, Rian. (1992). Women as Journalist: Incompatibility of Roles? Africa Media Review, 6(2).

[29] Wade-Gayles, Gloria. (1981). Black women journalists in the south. Callaloo, 11(13), 138-152.

[30] Weiss, Jessica. (2010). What challenges face female journalists in your region? Retrieved from http://ijnet.org/community/groups/10189/what-challengesface-female-journalists-your-region.

[31] Women in Media. (2010). Retrieved from http://archive.thedailystar.net/newDesign/newsdetails.php?nid=149785. 